Original Article

\title{
Expression of CD10, BCL-6 and MUM-1 Markers and Their Effects on Prognosis in Diffuse Large B Cell Lymphoma
}

\section{Diffüz Büyük B Hücreli Lenfoma'da CD10, BCL-6 ve MUM-1 Markerların Ekspresyonu ve Prognoz Üzerine Etkisi}

\author{
Ahmet Yozgat ${ }^{1}$, Benan Kasapoğlu², Nalan Akyürek ${ }^{3}$, Aytuğ Üner ${ }^{4}$ \\ ${ }^{1}$ Ufuk Üniversitesi Tıp Fakültesi, İç Hastalıkları ABD, Gastroenteroloji Bilim Dalı, Ankara \\ ${ }^{2}$ Lokman Hekim Üniversitesi Tıp Fakültesi, İç Hastalıkları ABD, Gastroenteroloji Bilim Dalı, Ankara \\ ${ }^{3}$ Gazi Üniversitesi Tıp Fakültesi, Tibbi Patoloji ABD, Ankara \\ ${ }^{4}$ Gazi Üniversitesi Tıp Fakültesi, İç Hastalıkları ABD, Medikal Onkoloji Bilim Dalı, Ankara
}

\begin{abstract}
Background and Aim: Immunohistochemistry may serve as a surrogate to define Diffuse large B-cell lymphoma (DLBCL) cases as germinal center B cell-like (GCB) or non-GCB subtypes and to provide prognostic information. In this study, we aimed to investigate the frequency and prognostic impact of CD10, B-cell lymphoma 2 and 6 (BCL2 and BCL6) and multiple myeloma oncogene 1 (MUM1) expressions in pathology sections of patients with DLBCL to determine the response of these subgroups to the rituximab including chemotherapy regimens.

Materials and Method: Patients were grouped into 2 regarding the chemotherapy regimens they were treated, as cyclophosphamide, doxorubicin, vincristine, and prednisone (CHOP) or Rituximab-CHOP. The treatment response, follow-up periods and outcomes of patients were recorded. The immunohistochemical panel was stained in pathology sections for CD10, BCL6 and MUM1/IRF 4 biomarkers. The patients were subgrouped as $\mathrm{GCB}$ or $\mathrm{ABC}$ regarding the immunohistochemical panel. Results: Totally 81 patients, (39 male, 42 female) were included in the study. At the time of diagnosis, CD10 was positive in 31 patients (38.3\%); BCL-6 in 53 patients (65.4\%); MUM-1 was positive in 47 patients $(58 \%)$ and BCL-2 was positive in 53 patients (65.4). With these results, 36 patients $(44.4 \%)$ were in the GCB group and 45 patients $(55.6 \%)$ were in the ABC group. No significant difference was found between the individual markers and subgroups in survival analyses.
\end{abstract}

Conclusion: We did not determine any significant effect of CD10, BCL-6, MUM-1 or BCL-2 positivity or GCB and non-GCB groups in the survival of patients with DLBCL.

Keywords: Diffuse large B-cell lymphoma; Prognostic Impact, ABC and GCB

\section{ÖZET}

Giriş ve Amaç: İmmünohistokimya kullanılarak, Diffüz büyük B hücreli lenfoma (DBBHL) vakaları germinal merkez $\mathrm{B}$ hücresi benzeri $(\mathrm{GCB})$ ve $\mathrm{ABC}$ grubu olmak üzere prognostik açıdan önemli olan alt tiplere ayrılabilir. Biz bu çalışmada DBBHL'li hastaların patoloji preparatlarında CD10, B hücreli lenfoma 2 ve 6 (BCL2 ve BCL6) ve multipl miyelom onkogen 1 (MUM1) markerlarının sıklığını ve rituksimab içeren kemoterapi gruplarındaki prognostik etkisini araştırmayı amaçladık.

Yöntem ve Gereçler: Hastalar, kemoterapi rejimleri açısından, siklofosfamid, doksorubisin, vinkristin ve prednizon (CHOP) veya Rituksimab-CHOP olarak 2'ye ayrıldı. Hastaların tedaviye yanıtı, takip süreleri ve tedavi sonuçları kaydedildi. Tanı anındaki patoloji preparatlarından CD10, BCL6 ve MUM1 / IRF 4 biyomarkerları için boyama yapılarak hastalar immünohistokimyasal panel açısından GCB veya $\mathrm{ABC}$ olarak alt gruplara ayrıld1.

Bulgular: Toplam 81 hasta (39 erkek, 42 kadın) çalışmaya dahil edildi. Tanı sırasında 31 hastada (\% 38,3) CD10; 53 hastada BCL-6 (\% 65,4); MUM-1 47 hastada (\% 58); BCL-2 53 hastada $(65,4)$ pozitifti. 
Bu sonuçlarla 36 hasta (\% 44.4) GCB grubu, 45 hasta (\% 55.6) ABC grubu olarak tanımlandı. Sağkalım analizinde gruplar ve biyomarkerlar arasında istatistiksel olarak anlamlı bir farklılık saptanmamıştır.

Tartışma ve Sonuç: DLBCL hastalarının sağkalımında CD10, BCL-6, MUM-1 veya BCL-2 pozitifliği veya $\mathrm{GCB}$ ve $\mathrm{ABC}$ gruplarının anlamlı bir etkisi saptanmamıştır.

Anahtar Kelimeler: Diffüz Büyük B Hücreli Lenfoma; Prognositk Etki, ABC ve GCB

\section{Introduction}

Diffuse large B-cell lymphoma (DLBCL) is the most common lymphoma type worldwide accounting for $30-40 \%$ of the cases. DLBCLs are derived from the germinal center or postgerminal center B cells. They are exceedingly heterogeneous with a wide variation in genetic features, morphology, and patient outcomes [1]. In more than half of the patients, longterm disease-free survival is expected but on the other hand, approximately $30-40 \%$ of patients do not respond properly to the current treatments [2-4]. In that aspect, some biomarkers are required to define the outcomes of DLBCL subgroups.

DLBCLs are classified as germinal center B cell-like (GCB) group, activated B cell-like $(\mathrm{ABC})$ group and unclassified group by gene expression profiling. Not only the morphology but also the therapeutic responses to these subgroups are known to be different from each other [5, 6]. Immunohistochemistry may serve as a surrogate to define DLBCL cases as GCB or non-GCB subtypes and to provide similar prognostic information as complementary DNA microarray does [7] because gene expression profiling studies are often long, costly and require fresh frozen tissue samples present in very few cases [8]. In that aspect, using some antibodies such as CD10, B-cell lymphoma 2 or 6 (BCL2 or BCL6), and multiple myeloma oncogene 1 (MUM1) algorithms have been developed to identify these subtypes [9].

In this study, we aimed to investigate the frequency and prognostic impact of CD10, BCL2, BCL6, and MUM1 expressions in pathology sections of patients with DLBCL to define the GCB and $A B C$ subgroups and to determine the prognostic impact of these subgroups to the rituximab including chemotherapy regimens.

\section{Material and Method}

Though 104 patients included in the study, 23 of them excluded due to lack of data. Totally 81 (39 male, 42 female) patients diagnosed with DLBCL and treated in Gazi University Medical Faculty, Medical Oncology Department, between January 1997 and October 2010 were analyzed in this study. The study was approved by the local ethics committee.

The patient records were retrospectively reviewed. The stages of patients were determined regarding Ann Arbor classification and IPI scores were recorded in all patients [10].

Patients were grouped into 2 regarding the chemotherapy regimens they were treated, as cyclophosphamide, doxorubicin, vincristine, and prednisone (CHOP) or Rituximab-CHOP. The treatment response, follow-up periods and outcomes of patients were recorded.

The pathology sections at the time of the first diagnosis were reached. Hematoxylin-Eosin stained and immunohistochemical sections of all patients were evaluated retrospectively. Moreover, in all patients, the immunohistochemical panel was stained in pathology sections for CD10, BCL-6, BCL-2 MUM1/IRF 4 biomarkers.

An immunohistochemical examination was performed to determine the CD 10, BCL-6, MUM-1 and BCL-2 expressions on formalinfixed paraffin sections using the streptavidinbiotin triple indirect immunoperoxidase method. Sections were cut to $4 \mu \mathrm{m}$ thickness, de-paraffinized in xylene and rehydrated through graded alcohol in distilled water. Antigen retrieval was done in a commercial buffer by autoclaving for 12 hours at $56{ }^{\circ} \mathrm{C}$. After autoclaving, sections were allowed to cool at room temperature for 20 minutes, 
Table 1. Antibodies used for immunohistochemical staining

\begin{tabular}{cllll}
\hline Antibody & Clon & Isotype & Dilution & Brand Name \\
\hline CD10 & 56 C6 & $\begin{array}{l}\text { Mouse } \\
\text { monoclonal }\end{array}$ & Ready to use & NovoCastra (UK) \\
BCL-6 & PG-B6p & $\begin{array}{l}\text { Mouse } \\
\text { monoclonal }\end{array}$ & $1: 50$ & $\begin{array}{l}\text { DakoCytomation } \\
\text { (Denmark) }\end{array}$ \\
MUM1 & MUM1p & $\begin{array}{l}\text { Mouse } \\
\text { monoclonal }\end{array}$ & Ready to use & $\begin{array}{l}\text { DakoCytomation } \\
\text { (Denmark) }\end{array}$ \\
BCL-2 & 124 & $\begin{array}{l}\text { Mouse } \\
\text { monoclonal }\end{array}$ & Ready to use & $\begin{array}{l}\text { DakoCytomation } \\
\text { (Denmark) }\end{array}$ \\
\hline
\end{tabular}

rinsed thoroughly with distilled water and placed in phosphate buffer saline (PBS). Endogenous peroxidase activity was blocked with hydrogen peroxide and, subsequently, slides were washed with PBS. All primary antibodies were incubated for 2 hours at room temperature. Following primary antibody incubation, sections were washed thoroughly with PBS and incubated with secondary antibody (Ultra streptavidin detection systemHRP; Signet, Massachusetts, USA) for 20 minutes at room temperature. Subsequently, sections were washed with PBS and incubated with Streptavidin-biotin complex (Dako Cytomation, Denmark) for 30 minutes at room temperature. Following a final wash with PBS, immunoreactivity was visualized with AEC (3-Amino 9-Ethylcarbazole; LabVision, Neomarkers, USA). Finally, sections were briefly counterstained with Mayer's hematoxylin and examined by light microscopy. Reactive tonsil tissues that were known to express the markers of interest were used as positive controls.

All specimens were analyzed in a semiquantitative way after a thorough examination of the whole immunostained slides. The ratio of positively stained tissues to all tumor tissues was determined. As defined before by Hans et al, more than $30 \%$ staining in tumoral cells was defined as positive [9]. The patients were subgrouped as $\mathrm{GCB}$ or $\mathrm{ABC}$ regarding the immunohistochemical panel.

Antibodies used for immunohistochemical staining and their brand names are summarized in Table 1.

\section{Statistical Analysis}

The Statistical Package for the Social Sciences program was used for data analysis (for Windows 17.0, SPSS Inc., USA). Variables were analyzed with the One-Sample Kolmogorov-Smirnow test for the determination of normal distribution. Normally distributing data were expressed as mean \pm standard deviation and non-normally distributing data were expressed as median (minimum-maximum). The Mann-Whitney test was used to compare $\mathrm{ABC}$ and $\mathrm{GCB}$ subgroups. In the comparison of more than 2 groups, Kruskal-Wallis variance analysis was performed. Pearson correlation analysis was performed to evaluate the correlation between CD10, BCL-6, MUM1, BCL-2, and other parameters.

Complete remission (CR) was defined as the total disappearance of tumors after treatment. Partial remission (PR) was defined as a more than $50 \%$ decrease in the tumor while stable disease (SD) was defined as less than $50 \%$ decrease or less than a $25 \%$ increase in the tumor. Progressive disease (PD) was defined as a more than a $25 \%$ increase in tumor or determination of new tumor foci.

The Kaplan-Meier survival curves and Log-rank test were used to represent the overall survival (OS) or progression-free survival (PFS) distributions. Overall survival was defined as the period from the time of diagnosis to death from any cause or the last contact. The significance level was set as $\mathrm{p} \leq$ $0.05 \%$. 


\section{Results}

Totally 81 patients, (39 male, 42 female) were analyzed in the study. The mean age of the patients was $56.1 \pm 14.8$ (range: $18-82$ ) years. The demographic and clinical features of patients regarding the immunohistochemical subgroups are summarized in Table 2. At the time of diagnosis, CD10 was positive in 31 patients $(38.3 \%)$, BCL-6 in 53 patients (65.4\%), MUM-1 was positive in 47 patients $(58 \%)$ and BCL-2 was positive in 53 patients (65.4). According to the algorithm defined by Hans et al, 36 patients $(44.4 \%)$ were in the GCB group and 45 patients $(55.6 \%)$ were in the ABC group. Patients were divided into two groups as $<60$ years (younger), $\geq 60$ years (elderly). While $47 \%$ of the patients in the GCB subgroup were young, $62 \%$ of the patients in the $\mathrm{ABC}$ subgroup were young, but the difference between these two groups was not statistically significant ( $\mathrm{p}=0.17$ ).

The median follow-up time was $27 \pm 24.08$ months in study participants. No significant difference was found between the individual markers and subgroups in terms of OS and PFS in survival analysis. In younger patients than in elderly patients and low-risk patients according to IPI risk scoring, OS and PFS durations were found to be higher. Besides, OS and PFS durations were significantly longer in patients with CR (Table 3).

Twenty-five $(69 \%)$ of the 36 patients in the GCB group received the R-CHOP regimen, and $11(31 \%)$ of them received the CHOP regimen, while $25(56 \%)$ of the 45 patients in the $\mathrm{ABC}$ group received $\mathrm{R}-\mathrm{CHOP}$ and 20 (44\%) of them received the CHOP regimen. The 5-year OS rate in the GCB group was $78 \%$ in the R-CHOP group and $49 \%$ in the CHOP group $(\mathrm{p}=0.90)$, while the 5 -year OS rate in the $\mathrm{ABC}$ group was $73 \%$ in the $\mathrm{R}$ CHOP group and it was $75 \%$ in the CHOP group $(\mathrm{p}=0.54)$ (Figures $1 \mathrm{a}$ and $1 \mathrm{~b})$.

Of the 28 BCL-6 (-) patients, $21(75 \%)$ received the R-CHOP regimen while 7 (25\%) received the $\mathrm{CHOP}$ regimen. Of the 53 patients with BCL-6 (+), 29 (55\%) received the $\mathrm{R}-\mathrm{CHOP}$ regimen and $24(45 \%)$ received the $\mathrm{CHOP}$ regimen. In the BCL-6 (-) patient group, the 5-year OS rate was $54 \%$ in the R$\mathrm{CHOP}$ regimen group and $57 \%$ in the $\mathrm{CHOP}$ regimen group $(\mathrm{p}=0.51)$. In the BCL-6 $(+)$ patient group, the 5-year OS rate was $84 \%$ in the R-CHOP regimen group and $72 \%$ in the CHOP regimen group $(\mathrm{p}=0.60)$.

When the CHOP and $\mathrm{R}-\mathrm{CHOP}$ regimens were compared according to the 5-year OS and 3year PFS rates, OS and PFS rates were higher in the group receiving $\mathrm{R}-\mathrm{CHOP}$ regimen but did not reach a statistically significant level (5-year OS rates were $76 \%$ and $64 \%$, respectively) $(\mathrm{p}=0.39)$.

When patients were analyzed according to their chemotherapy (CT) regimens, adding rituximab to CT increased the 5-year OS rate in the GCB group, but this did not reach a statistically significant level (Table 4).

\section{Discussion}

In this study, we have analyzed the role of immunostaining in predicting the prognosis of patients with DLBCL who were treated with CHOP or R-CHOP. We determined that, among study participants, $44.4 \%$ were in the GCB group and $55.6 \%$ were in the $\mathrm{ABC}$ group. The rates of CD10, BCL-6, MUM-1 and BCL-2 positivity were $38.3 \%, 65.4 \%$, $58 \%$ and $65.4 \%$, respectively. Any significant difference was not found between the individual markers and subgroups in terms of OS and PFS in survival analysis.

Regarding the morphological features, DLBCLs are classified as GCB, ABC and unclassified groups by gene expression profiling. Masir et al [11] reported the GCB subtype in $37 \%$ and $\mathrm{ABC}$ subtype in $49 \%$ of patients. Wawire et al [12] reported the GCB cell type in $40.6 \%$ of 165

DLCBL patients in their study. We reported the GCB and ABC prevalence as $44.4 \%$ and $55.6 \%$, respectively; and our data were compatible with the literature.

Prognostic factors in DLBCL are highly important in management and determining appropriate treatment modalities. For that reason, immunohistochemical markers have been studied before, but conflicting results are present in previous literature. 
Table 2: Demographical and clinical features of patients regarding the immunohistochemical subgroups

\begin{tabular}{|c|c|c|c|c|}
\hline Characteristics & $\begin{array}{c}\mathrm{ABC} \\
\mathrm{n}(\%)^{\star \star}\end{array}$ & $\begin{array}{l}\text { GCB } \\
\mathrm{n}(\%)^{* *}\end{array}$ & Total $(\mathrm{n} / \%)^{*}$ & $\mathrm{p}^{\mathrm{a}}$ \\
\hline \multicolumn{5}{|l|}{ Gender } \\
\hline Male & $21(46.7)$ & $18(50)$ & $39(48.1)$ & 0.765 \\
\hline Female & $24(53.3)$ & $18(50)$ & $42(51.9)$ & \\
\hline \multicolumn{5}{|l|}{ Age( years) } \\
\hline$<60$ & $28(62.2)$ & $17(47.2)$ & $45(55.6)$ & 0.177 \\
\hline$\geq 60$ & $17(37.8)$ & $19(52.8)$ & $36(44)$ & \\
\hline \multicolumn{5}{|l|}{ Stage (Ann-Arbor) } \\
\hline 1 & $6(13.3)$ & $8(22.2)$ & $14(17.3)$ & NA \\
\hline 2 & $24(53.3)$ & $12(33.3)$ & $36(44.4)$ & \\
\hline 3 & $11(24.4)$ & $8(22.2)$ & $19(23.5)$ & \\
\hline 4 & $4(8.9)$ & $8(22.2)$ & $12(14.8)$ & \\
\hline \multicolumn{5}{|l|}{ B symptom } \\
\hline Present & $24(53.3)$ & $18(50)$ & $42(51.9)$ & 0.765 \\
\hline Absent & $21(46.7)$ & $18(50)$ & $39(48.1)$ & \\
\hline \multicolumn{5}{|l|}{ Bulky mass } \\
\hline Present & $22(48.9)$ & $6(16.7)$ & $28(34.6)$ & 0.002 \\
\hline Absent & $23(51.1)$ & $30(83.3)$ & $53(65.4)$ & \\
\hline \multicolumn{5}{|l|}{$\mathrm{LDH}$} \\
\hline$\leq \mathrm{N}$ & $20(44.4)$ & $19(52.8)$ & $39(48.1)$ & 0.456 \\
\hline$>\mathrm{N}$ & $25(55.6)$ & $17(47.2)$ & 42 (51.9) & \\
\hline \multicolumn{5}{|l|}{ ECOG performance } \\
\hline 0 & $10(22.2)$ & $4(11.1)$ & $14(17.3)$ & NA \\
\hline 1 & $21(46.7)$ & $21(58.3)$ & 42 (51.9) & \\
\hline 2 & $5(11.1)$ & $5(13.9)$ & $10(12.3)$ & \\
\hline 3 & $7(15.6)$ & $5(13.9)$ & $12(14.8)$ & \\
\hline 4 & $2(4.4)$ & $1(2.8)$ & $3(3.7)$ & \\
\hline \multicolumn{5}{|l|}{ EN involvement } \\
\hline+ & $29(64.4)$ & $23(63.9)$ & $52(64.2)$ & 0.959 \\
\hline- & $16(35.6)$ & $13(36.1)$ & $29(35.8)$ & \\
\hline \multicolumn{5}{|l|}{ IPI risk group } \\
\hline $0-1$ & $25(55.6)$ & $21(58.3)$ & $46(58.6)$ & NA \\
\hline 2 & $10(22.2)$ & $4(11.1)$ & $14(17.3)$ & \\
\hline 3 & $7(15.6)$ & $6(16.7)$ & $13(16)$ & \\
\hline $4-5$ & $3(6.7)$ & $5(13.9)$ & $8(9.9)$ & \\
\hline \multicolumn{5}{|l|}{ IPI } \\
\hline 0 & 15 (33.3) & $10(27.8)$ & $25(30.9)$ & NA \\
\hline 1 & $10(22.2)$ & $11(30.6)$ & $21(25.9)$ & \\
\hline 2 & $10(22.2)$ & $4(11.1)$ & $14(17.3)$ & \\
\hline 3 & $7(15.6)$ & $6(16.7)$ & $13(16)$ & \\
\hline $4-5$ & $3(6.7)$ & $5(13.9)$ & $8(9.9)$ & \\
\hline \multicolumn{5}{|l|}{ Treatment } \\
\hline $\mathrm{R}-\mathrm{CHOP}$ & $25(55.69$ & $25(69.4)$ & $50(61.7)$ & 0.201 \\
\hline $\mathrm{CHOP}$ & $20(44.4)$ & $11(30.6)$ & 31 (38.3) & \\
\hline \multicolumn{5}{|l|}{ Treatment Response } \\
\hline Unevaluated & $1(2.2)$ & $1(2.8)$ & $2(2.5)$ & NA \\
\hline CR & $37(82.2)$ & $30(83.3)$ & $67(82.7)$ & \\
\hline PR & $5(11.1)$ & $1(2.8)$ & $6(7.4)$ & \\
\hline SD & $1(2.2)$ & $1(2.8)$ & $2(2.5)$ & \\
\hline PD & $1(2.2)$ & $3(8.3)$ & $4(4.9)$ & \\
\hline
\end{tabular}
involvement; CR:Complete remission; PR: Parita remission; SD:Stabil disease; PD:Progressive disease 
Table 3: The effects of subgroups and general patient characteristics on OS and PFS

\begin{tabular}{|c|c|c|c|c|c|c|}
\hline & & Number (\%) & 5 year OS (\%) & $p$ & 3 year PFS (\%) & $\mathrm{pA}$ \\
\hline \multirow[t]{2}{*}{ Age } & $<60$ & $45(56)$ & 91 & 6 & 85 & 4 \\
\hline & $>60$ & $36(44)$ & 47 & & 51 & \\
\hline \multirow[t]{4}{*}{ Stage } & 1 & $14(17)$ & 61 & 0.34 & 77 & 0.32 \\
\hline & 2 & $36(44)$ & 79 & & 74 & \\
\hline & 3 & $19(24)$ & 53 & & 50 & \\
\hline & 4 & $12(15)$ & 75 & & 75 & \\
\hline IPI risk & $0-1$ & $46(57)$ & 84 & 5 & 83 & 6 \\
\hline \multirow{3}{*}{ group } & 2 & 14(17) & 45 & & 55 & \\
\hline & 3 & $13(16)$ & 29 & & 42 & \\
\hline & $4-5$ & $8(10)$ & 62 & & 62 & \\
\hline \multirow[t]{2}{*}{ LDH } & $<\mathrm{N}$ & $39(48)$ & 45 & 0.25 & 70 & 0.18 \\
\hline & $>\mathrm{N}$ & $42(52)$ & 68 & & 69 & \\
\hline \multirow[t]{2}{*}{ EN involvemer } & Yok & $29(36)$ & 69 & 0.45 & 63 & 0.30 \\
\hline & Var & $52(64)$ & 65 & & 72 & \\
\hline \multirow[t]{2}{*}{ KT group } & $\mathrm{RCHOP}$ & $50(62)$ & 73 & 0.60 & 76 & 0.39 \\
\hline & $\mathrm{CHOP}$ & $31(38)$ & 67 & & 64 & \\
\hline \multirow[t]{5}{*}{ Response } & $D^{*}$ & $2(2)$ & 0 & $<0.001$ & 0 & $<0.001$ \\
\hline & CR & $67(84)$ & 79 & & 79 & \\
\hline & PR & $6(7)$ & 33 & & 25 & \\
\hline & SD & $2(2)$ & 50 & & 50 & \\
\hline & PD & $4(5)$ & 25 & & 25 & \\
\hline \multirow{2}{*}{ CD10 } & $(-)$ & $50(62)$ & 74 & 0.43 & 77 & 0.39 \\
\hline & $(+)$ & $31(38)$ & 65 & & 57 & \\
\hline \multirow[t]{2}{*}{ BCL-6 } & $(-)$ & $28(35)$ & 62 & 0.20 & 67 & 0.15 \\
\hline & $(+)$ & $53(65)$ & 74 & & 72 & \\
\hline \multirow[t]{2}{*}{ MUM-1 } & $(-)$ & $34(42)$ & 62 & 0.43 & 59 & 0.37 \\
\hline & $(+)$ & $47(58)$ & 77 & & 79 & \\
\hline \multirow[t]{2}{*}{ BCL-2 } & $(-)$ & $28(35)$ & 58 & 0.46 & 67 & 0.42 \\
\hline & $(+)$ & $53(65)$ & 72 & & 68 & \\
\hline GCB group & & $36(44)$ & 63 & 0.55 & 60 & 0.51 \\
\hline$A B C$ group & & $45(56)$ & 77 & & 78 & \\
\hline
\end{tabular}

Table 4: 5-year OS rates in subgroups according to chemotherapy regimens

\begin{tabular}{cccc}
\hline & & 5 year OS $(\%)$ & $p$ \\
\hline R-CHOP & GCB & 78 & 0.64 \\
& ABC & 73 & \\
CHOP & GCB & 62 & 0.55 \\
& ABC & 75 & \\
\hline
\end{tabular}

* Pearson chi-square analysis

Akyurek et al [13] reported that BCL-6 rearrangement predicted significantly shorter overall survival while BCL-2 rearrangement had no prognostic impact on outcome in 239 patients with DLBCL. Bodoor et al [14] investigated the role of BCL-6, CD10, CD138 and MUM-1 expressions in the prognosis of patients with DLBCL and reported that BCL6 expression was associated with better overall survival without any impacts of CD10 and MUM-1 on survival.
Culpin et al [15] assessed the prognostic validity of immunohistochemical markers and algorithms identified in the CHOP era in immunochemotherapy-treated DLBCL patients and reported that low CD10 $(<10 \%)$, low LMO2 $(<70 \%)$ or high BCL-2 $(\geq 80 \%)$ predicted shorter OS and high BCL-2 $(\geq 80 \%)$, low BCL-6 $(<60 \%)$, low GCET1 $(<20 \%)$ or low LMO2 $(<70 \%)$ predicted shorter PFS. Hassan et al [16] reported that CD-10 expression in DLBCL was associated with 


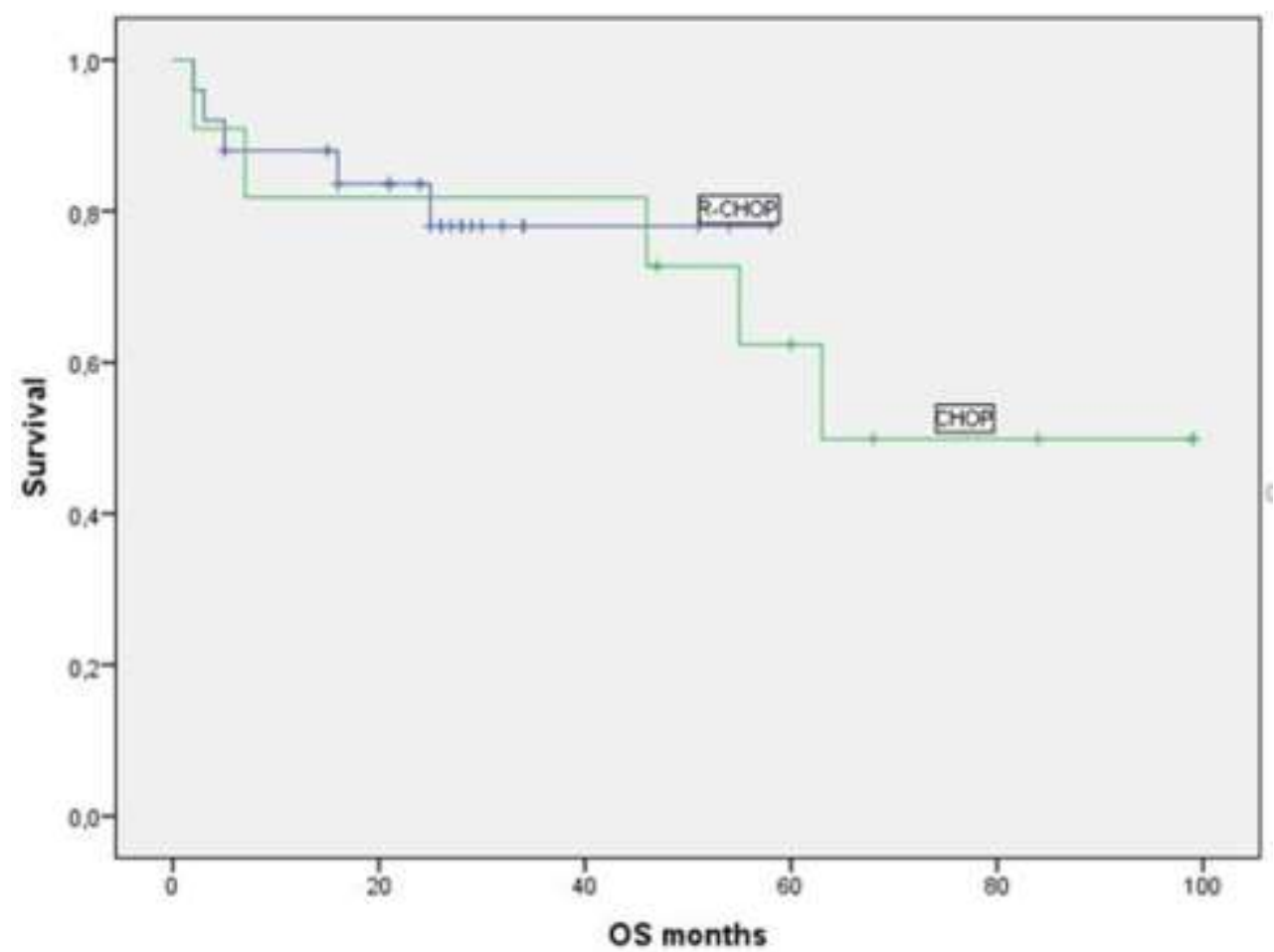

Figure 1a: Chemotherapy-related OS durations in the GCB subgroup (Kaplan-Meier curve)

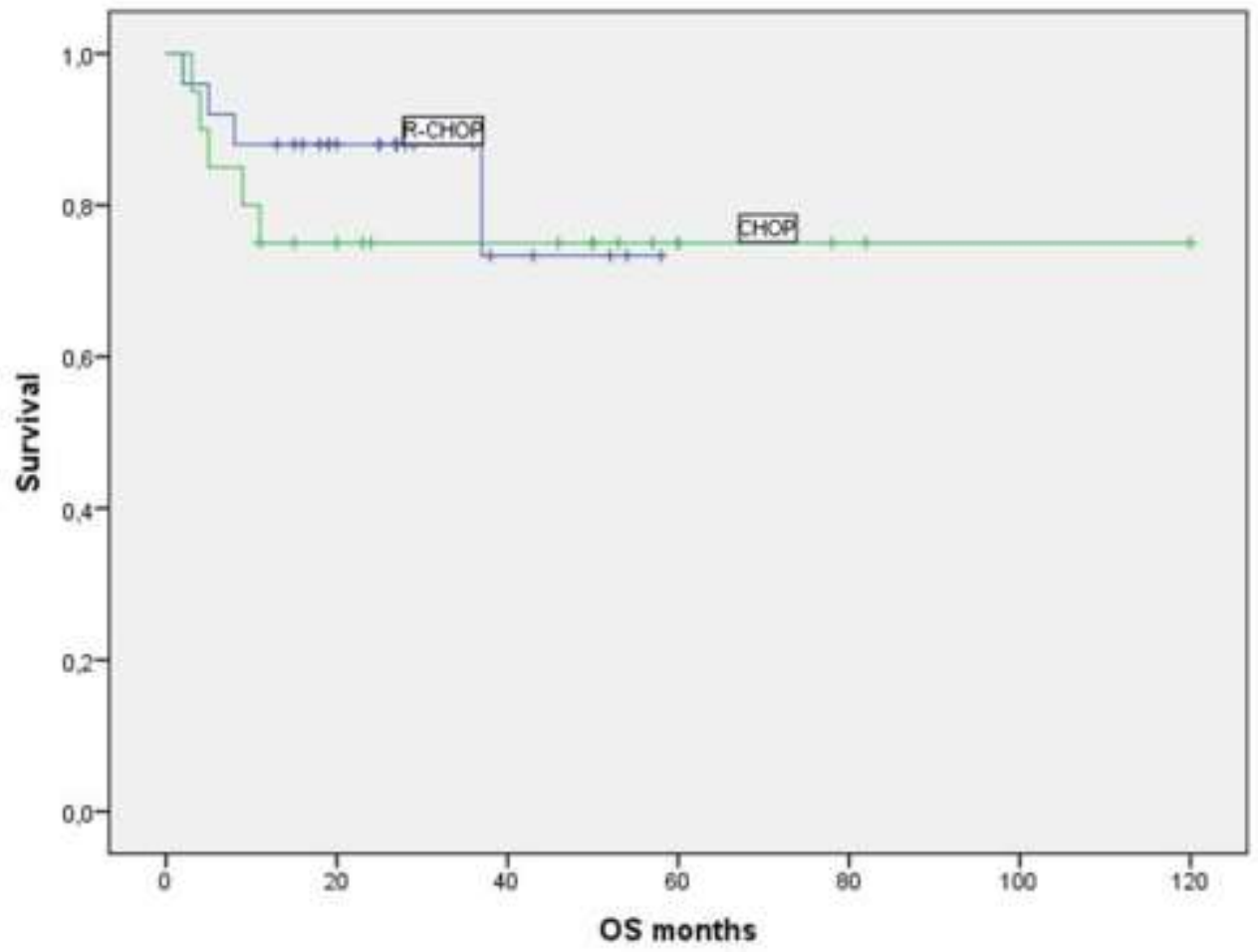

Figure 1b: Chemotherapy-related OS durations in the ABC subgroup (Kaplan-Meier curve) 
better immediate clinical response whereas MUM-1 expression was associated with poor immediate clinical response. However, there was no statistically significant association of BCL-6 with an immediate clinical response that was noted after 6 cycles of chemotherapy. Jia et al [17] reported that, among Uygur patients diagnosed with DLBCL, expression of germinal center B (GCB) cell-expressed transcript-1, FOXP1, CD10, BCL-6, and MUM1 was associated with a significantly higher 3-year OS. Dwivedi et al [18] did not determine any statistically significant difference regarding the survival rates between GCB and non-GCB subtypes of DLBCL patients. Recently, in a detailed study of Lu et al [19], using immunohistochemistry and fluorescence in situ hybridization, the prognostic value of Hans algorithm was investigated in 306 cases who were treated with chemoimmunotherapy and GCB subtype was reported to have a better OS and PFS than non-GCB cases. On the other hand, it was also reported that double-positive $(\mathrm{CD} 10(+)$, MUM1(+)) patients showed similar OS and PFS with the non-GCB group while the (triple-negative (CD10(-), BCL6(-), MUM(-) group) showed similar OS and PFS with the GCB group. Similarly, Chang et al [20] also did not determine any difference in survival of patients with GCB or non-GCB tumors. Although GCB tumors more frequently expressed CD10 and BCL-6 as well as the BCL2 and MYC rearrangements with less

\section{REFERENCES}

1. Martelli M, Ferreri AJ, Agostinelli C, Di Rocco A, Pfreundschuh $M$, Pileri SA. Diffuse large B-cell lymphoma. Critical reviews in oncology/hematology. 2013; 87(2): 146-71.

2 Kubuschok B, Held G, Pfreundschuh M. Management of diffuse large B-cell lymphoma (DLBCL). Cancer treatment and research. 2015; 165: 271-88.

3 Simon R. Genomic biomarkers in predictive medicine: an interim analysis. EMBO molecular medicine. 2011;3(8):429-35.

4 Sehn LH. Paramount prognostic factors that guide therapeutic strategies in diffuse large B-cell frequent expression of MUM1. Abdulla et al reported that concurrent expression of MYC and BCL-2 proteins was strongly associated with inferior survival in DLBCL patients treated with R-CHOP [21].

The main limitations of this study are the retrospective design, the low number of patients and the low follow up time.

In the present study, the 5-year OS rate in patients receiving R-CHOP therapy was $78 \%$ in the GCB group, while it was $49 \%$ in the group receiving $\mathrm{CHOP}$ therapy. The 5-year OS difference in the GCB subgroup is remarkable at $29 \%$ among the treatment groups. A similar difference was not detected among the treatment groups in the $\mathrm{ABC}$ subgroup (73\% in the R-CHOP group, $75 \%$ in the CHOP group). Despite this remarkable difference, the difference between the treatment groups in the GCB group was statistically nonsignificant and may be related to the limitations of the study, the low number of patients who reach the primary endpoint, and especially the number of patients.

In conclusion, we did not determine any significant effect of CD10, BCL-6, MUM-1, or BCL-2 positivity or GCB and non-GCB groups in the survival of patients with DLBCL. The addition of rituximab can contribute to treatment success, particularly in the GCB subgroup. Further, prospective, larger studies are warranted to determine the exact role of these markers in the prognosis of DLBCL. lymphoma. Hematology American Society of Hematology Education Program. 2012; 2012: 402-9.

5 Muris JJ, Meijer CJ, Vos W, et al. Immunohistochemical profiling based on $\mathrm{Bcl}-2, \mathrm{CD} 10$ and MUM1 expression improves risk stratification in patients with primary nodal diffuse large B cell lymphoma. J Pathol. 2006; 208(5):714-23.

6 Hwang HS, Park CS, Yoon DH, Suh C, Huh J. High concordance of gene expression profiling-correlated immunohistochemistry algorithms in diffuse large Bcell lymphoma, not otherwise specified. Am J Surg Pathol. 2014; 38(8):1046-57.

7 Visco C, Li Y, Xu-Monette ZY, et al. Comprehensive gene expression profiling and immunohistochemical studies support application of immunophenotypic 
algorithm for molecular subtype classification in diffuse large B-cell lymphoma: a report from the International DLBCL Rituximab-CHOP Consortium Program Study. Leukemia. 2012; 26(9): 2103-13.

8 de Jong $D$, Rosenwald $A$, Chhanabhai $M$, et al. Immunohistochemical prognostic markers in diffuse large B-cell lymphoma: validation of tissue microarray as a prerequisite for broad clinical applications--a study from the Lunenburg Lymphoma Biomarker Consortium. J Clin Oncol 2007; 25(7): 805-12.

9 Hans CP, Weisenburger DD, Greiner TC, et al. Confirmation of the molecular classification of diffuse large B-cell lymphoma by immunohistochemistry using a tissue microarray. Blood. 2004;103(1):275-82. 10 International Non-Hodgkin's Lymphoma Prognostic Factors P. A predictive model for aggressive nonHodgkin's lymphoma. New Eng J Med. 1993; 329(14): 987-94.

11 Masir N, Akhter A, Roshan TM, et al. Diffuse large B-cell lymphoma in Southeast Asian cohort: expression patterns of $B$-cell receptor (BCR) repertoire and its linkage with molecular subtypes and response to RCHOP therapy. J Clin Pathol. 2019; 72(9):630-5.

12 Wawire J, Sayed S, Moloo Z, Sohani AR. Diffuse Large B-Cell Lymphoma in Kenya: MYC, BCL2, and the Cell of Origin. J Global Oncol. 2019; 5:1-8.

13 Akyurek N, Uner A, Benekli M, Barista I. Prognostic significance of MYC, BCL2, and BCL6 rearrangements in patients with diffuse large B-cell lymphoma treated with cyclophosphamide, doxorubicin, vincristine, and prednisone plus rituximab. Cancer. 2012; 118(17):4173-83.

14 Bodoor K, Matalka I, Hayajneh R, Haddad Y, Gharaibeh W. Evaluation of BCL-6, CD10, CD138 and MUM-1 expression in diffuse large B-cell lymphoma patients: CD138 is a marker of poor prognosis. Asian

Corresponding author e-mail: a_yozgat@yahoo.com

Orcid ID:

Ahmet Yozgat 0000-0002-4414-9929

Benan Kasapoğlu 0000-0003-3858-0103

Nalan Akyürek 0000-0002-2644-4609

Aytuğ Üner 0000-0003-3836-3854

Doi: $10.5505 /$ aot.2021.35403
Pacific journal of cancer prevention: APJCP. 2012;13(7):3037-46.

15 Culpin RE, Sieniawski M, Angus B, et al. Prognostic significance of immunohistochemistry-based markers and algorithms in immunochemotherapy-treated diffuse large B cell lymphoma patients. Histopathology. 2013; 63(6):788-801.

16 Hassan $U$, Ishtiaq $S$, Hussain $M$. Immunohistochemical expression of CD-10, BCL-6 and MUM-1 antibodies and immediate clinical response in patients of diffuse large B-cell lymphomas after six cycles of chemotherapy. Journal of the College of Physicians and Surgeons--Pakistan: JCPSP. 2014; 24(10):722-7.

17 Jia CD, Liang LP, Yang LL, Yue N, Zhao F, Bai JP. Immunological subtypes analysis of Uygur diffuse large B-cell lymphoma in Xinjiang and their prognostic significance. J Cancer Res Therap. 2015; 11(4): 852-6.

18 Dwivedi A, Mehta A, Solanki P. Evaluation of immunohistochemical subtypes in diffuse large B-cell lymphoma and its impact on survival. Indian journal of pathology \& microbiology. 2015; 58(4): 453-8.

19 Lu TX, Miao Y, Wu JZ, et al. The distinct clinical features and prognosis of the CD10(+) MUM1(+) and CD10(-) Bcl6(-) MUM1(-) diffuse large B-cell lymphoma. Scientific reports. 2016; 6: 20465.

20. Chang ST, Chen SW, $\mathrm{Ho} \mathrm{CH}$, et al. Immunophenotypic and genetic characteristics of diffuse large B-cell lymphoma in Taiwan. Journal of the Formosan Medical Association = Taiwan yi zhi. 2016; 115(11):961-7.

21. Abdulla M, Laszlo S, Triumf J, et al. A populationbased study of cellular markers in R-CHOP treated diffuse large B-cell lymphoma patients. Acta Oncol. 2016; 55(9-10):1126-31. 